LET: Linguistics, Literature and English Teaching Journal

||Volume||10||Issue||2||Pages||116-136||2020||

|P-ISSN: 20869606; E-ISSN: 25492454|

Available online at:http://jurnal.uin-antasari.ac.id/index.php

\title{
THE MAPPING OF MOVEMENT VERBS FOUND IN THE GOOD EARTH
}

\begin{tabular}{|c|c|}
\hline Bali Dwi & $\begin{array}{l}\text { I Made Juliarta } \\
\text { uliarta330@gmail.com } \\
\text { a University of Indonesia }\end{array}$ \\
\hline Article History: & $\begin{array}{l}\text { This study aimed at focussing the translation of } \\
\text { movement verbs in The Good Earth written by }\end{array}$ \\
\hline Received: $31^{\text {st }}$ August 2020 & Pearl S. Buck. The Natural Semantic \\
\hline Accepted: $20^{\text {th }}$ December 2020 & $\begin{array}{l}\text { Metalanguage (NSM) is applied in translation } \\
\text { process. The novel The Good Earth was chosen }\end{array}$ \\
\hline Corresponding Author: & $\begin{array}{l}\text { as data source because it has two texts which } \\
\text { have different language types. This study has the } \\
\text { purpose to describe the application of translation } \\
\text { procedures that is proposed by Vinay and }\end{array}$ \\
\hline madejuliarta330@gmail.com & $\begin{array}{l}\text { Darlbener and it is applied to examine the } \\
\text { mapping of Action Verbs by the NSM (Natural }\end{array}$ \\
\hline $\begin{array}{l}\text { Semantic mapping; Natural } \\
\text { semantic metalanguage; } \\
\text { Verb; Translation; Action } \\
\text { Verb }\end{array}$ & $\begin{array}{l}\text { Semantic Metalanguage) theory. The analysis } \\
\text { was shown as the mapping between Indonesian } \\
\text { and English action verbs which was presented } \\
\text { into the subtype of the verbs based on the } \\
\text { classification. This study attempts to apply that } \\
\text { theory in solving the problem of the different } \\
\text { language. Semantic mapping (SM) is a method } \\
\text { in statistics for dimensionality reduction that can } \\
\text { be used in a set of multidimensional vectors of } \\
\text { features to extract a few new features that } \\
\text { preserves the main data characteristics. }\end{array}$ \\
\hline
\end{tabular}

I Made Juliarta 


\section{INTRODUCTION}

Language can be meant as an important part of human. Sometimes, it is found that the difficulty in translating to some people who try getting the message or information from other languages. It is found as there are the differences between the nature of source language and target language, and the abilities of translators in translating from English into Indonesian. Translation is stated as important as it is needed in Indonesia which is known as a developing country. Indonesia is known in terrns of education, culture, and technology. Translation is very important in various areas which are used to translate from one language into another language. However, it is not all the references written in Indonesian as they are coming from different countries and using different languages. As we know that the translation is used in transferring the message from foreign languages into Indonesian. Translation plays an important role in transferring the information from other countries into Indonesian. The intended meaning can play an important role in translation. According to Goddard (1997:2), meaning is not reference, because some words don't have reference and those words which are not meaningless. According to him, teher are relation between meaning and reference as reference made the use of particular expression on a particular situation. This study uses the theory of semantic metalanguage. The NSM itself can represent a set of claimed findings about the language universals which tell about the existance of a speciable set. The NSM can be stated as an object of the study in its own right. It's stated as an invaluable descirptive tools in the analysis and constrastive study of meaning related in all languages. It is the semantic explication that the formal mode of representing the meaning. However, it depends on the meaning expression. It is said that the meaning is not scientific knowledge because it is the meaning that must be explained in simpler way and more easily understood terms. According to Crystal (2008:298), the topic of meaning in the context of language necessitates reference to non-linguistic factors, such as thought, situation, knowledge, intention and use. It is important to know the intended meaning and the cultural background effect. They produce the different translation product. Someone's feeling toward the others or the 
environment can be expressed by every lexicon. Natural Semantic Metalanguage is applied to examine data which is taken from the novel. This study attempts to apply that theory in solving the problem of the different language. Semantic mapping (SM) is one of a method in statistics for dimensionality reduction that can be used in a set of multidimensional vectors of features to extract few new features that preserves the main data characteristics. Semantic mapping performs dimensionality reduction by clustering the original features in semantic clusters and combining features mapped in the same cluster to generate an extracted feature. Given a data set, this method constructs a projection matrix that can be used to map a data element from a high-dimensional space into a reduced dimensional space. Semantic mapping can be applied in construction of text mining and information retrieval systems, as well as systems managing vectors of high dimensionality. Semantic mapping is an alternative to random mapping, principal components analysis and latent semantic indexing methods. It can be seen that there are previous studies that are related to this study. First, the research that is written by Suryasa (2016) entitled :Ngalap in Balinese: A Natural Semantic Metalanguage Approach". This study has the purpose to analyze about the meaning of an action Balinese verbs in which this study used qualitative research in discussing "pick up" concept in Balinese that is traslated into ngalap. Suryasa (2016) in this study, the metalanguage approach analyzed the collected data, meanwhile in this study also analyzed the data using the metalanguage approach. The lexicon of ngalap with their variations can describe semantic structure by using the sub-component " $\mathrm{X}$ did something". The collected data are also analyzed using natural semantic metalanguage theory. This theory also combines the philosophical and logical tradition in the study. Second, the research that is written by Aulia (2017) entitled "The Effectiveness of Semantic Mapping on Student's Vocabulary Achievement". This study analyzes about the technique in vocabulary by using semantic mapping. Semantic mapping is stated as a form of graphic organizers, leads learners to design a visual presentation of relationships among words, meanings, and images. This study analyzes that there are some advantages like helping students to remember the new words easily, and 
increase student's motivation to learn new vocabulary. This study has the purpose to increase's vocabulary knowledge and improve the vocabulary achievement. The third study entitles "Enriching Students vocabulary through Semantic Mapping" that is written by Siti Nur Fadilah. It can be seen in this study that this study conducted research at X Electro B class at Vocational School. This study has the purpose to enriche the student's vocabulary by using semantic mapping strategy. This study applied a collaborative classroom action research. It is stated the result of this study that there are some improvements in positive responses of teaching-learning process in vocabulary by doing semantic mapping. Fourth, the research that is written by Aksyah (2017) entitled "The Implementation of Semantic Mapping Strategy in Mastering English Vocabulary". This study analysis about the improvement of implementation of Semantic Mapping Strategy in teaching Vocabulary and also to find out the student's opinion about the strategy. This study used 40 students in experimental class and controlled class. It is stated in this study that the sampling technique is choosen by using purposive sampling. The data in this study is analysed by using SPSS. The explications are in form of the intuitive senses for native speakers. The another condition is in the form well-formedness. They must be framed entirely in the semantic primes or molecules in order to conform for the syntax of the natural semantic metalanguage. It is stated that over the 35 years since Wierzbicka's (1972) Semantic Primitives, the NSM program has improved into new models of semantic explication. As we know that NSM researchers have improved proposals for the structure of few subclasses of physical verbs, such as (a) routine bodily processes, such as eating and drinking, and verbs of locomotion, like walking, running, jumping, (b) verbs of physical contact, like hit, punch, slap, kick, and (c) complex physical activity verbs (typically involving instruments), such as cutting and chopping Wierzbicka (2009). This study used a collaborative classroom action research. It can be meant that the result of this study that there are few improvements in positive responses of teaching-learning process in vocabulary by doing semantic mapping. 


\section{METHOD}

The materials in this research were taken from the novel entitled The Good Earth. These stories can be said as fiction or narrative story. The novel was chosen as these novels performed in two languages which were in the form of Indonesian and English. It is important to get the collected data by reading and documenting technique which were considered relating to problems. The data were compiled by reading Indonesian and English novel. The qualitative method and library research were used in analyzing data. The appropriate data were analyzed. There are some elimination of the data used in finding the appropriate data. The data that are collected are then analyzed using metalanguage approach. The author only choose the data that were really needed by the author with some requirements in supporting this study. The data were then analyzed by using the theory proposed that is proposed by Wierzbicka (1996). A metalanguage is stated as merely another language, in which it is an artificial and not a natural language. Wierzbicka (1996) stated that the basic requirement for metalanguage is to get the satisfaction to communicate the meaning from. This can also be the entity, process, result, instruments, and emotional state. Givon (1984) stated that the verbs can be divided into three classification, namely: state verb, process verb, and also an action verb. The action verb can come from act by someone. Goddard (1997) stated that there is an agreement in which the semantic can give an illuminating account of meaning relation. Semantic mapping is stated as the strategy for representing the concepts. A semantic word map can allow the students to explore the knowledge of the new word by mapping it. The semantic map can lead the learners to design a visual representation. Crystal (2008:298), stated that the topic of meaning in the context of language necessitates reference to non-linguistic factors, such as thought, situation, knowledge, intention and use. We need to know the intended meaning and the cultural background effect. They can produce the different translation product. Someone's feeling toward the others or the environment can be expressed by every lexicon. Natural Semantic Metalanguage is applied to examine data which is taken from the novel. This study aims at applying that theory in solving the problem of the different language. Semantic 
mapping (SM) is stated as one of a method in statistics for dimensionality reduction that can be used in a set of multidimensional vectors of features to extract few new features that preserves the main data characteristics. Semantic mapping can perform dimensionality reduction by clustering the original features in semantic clusters and combining features mapped in the same cluster to generate an extracted feature. It is state that the validity of NSM explication is tested based on on the two main conditions. In the substitutability in a broad sense, explication can make intuitive sense to native speakers when it is substituted into into the context of use. In well-formedness, they are framed entirely in semantic primes or molecules, in order to conform in a coherence condition. In the syntax properties of sematic primes, are in literally universals of syntax. They can be divided into three types, those are: basic combinatorics, for example that substantive primes and relational substantives and can combine with specifiers in order to form semantic units, those are: this thing, someone else, the same place. NSM analysis is stated as a demanding process. There are two main conditions in the validity of NSM explication. The explications are in the intuitive senses for native speakers. The another condition is in well-formedness. They need to be framed entirely in the semantic primes or molecules in order to conform for the syntax of the natural semantic metalanguage. It is stated that over the 35 years since Wierzbicka's (1972) Semantic Primitives, the NSM program has been converted into new models of semantic explication. A semantic molecule can be meant as a packet of semantic components which has the meaning of a lexical unit. In semantic molecules, there is a special cognitive significance in that they allow a conceptual chunking which makes it possible to control the concepts of semantic complexity. It should be said that there are some recurrent components that are not in thesemantic molecules, because they are not encapsulated as the meanings of lexical items. It is important to point out the descriptive components of an explication such as they are not intended as an external, objective description of the referents. (Wierzbicka 1996a: 344) stated that They are aimed at "capturing what is psychologically real and linguistically relevant (from the point of view of native speakers of English)". Terms for few natural kinds and artifacts 
can describe tremendous amounts of cultural knowledge. For example, it can be seen that for cats a full explication will include that they chase, catch, and eat small creatures, that they can climb well and move quietly, that they can see in the dark, and that they often sleep for short periods in the day. It can be seen for animal species with which people have close relationships, like cat (dog, horse, or mouse), the 'behavior' and 'relation with people' sections can describe to 10-20 lines of semantic text. However, the components are not encyclopedic in the sense of representing objective facts about the class of referents.

\section{FINDINGS AND DISCUSSIONS}

The data were analysed deeply by using the theory of Natural Semantic Metalanguage (NSM). Natural Semantic Metalanguage (NSM), there are few lexicons that are emotions, speech acts, and causatives. There are some syntactic properties of semantic primes which are literally universals of syntax. There are relational substantives and can combine with specifiers in order to form semantic units: this thing, someone else, the same place. Therefore, by applying the mapping process, the meaning of the verbs can be observed. According to Givon (1984) in his book entitled Syntax: a Functional Typological Introduction, we know that the verb can be classified into a couple of typological classifications which follows the typological classification model. In the discussion part, the appropriate data were analyzed. There are some elimination of the data used in finding the appropriate data. The author only choose the data that were really needed by the author with some requirements in supporting this study. The data are analysed by using the theory proposed that is proposed by Wierzbicka (1996). A metalanguage is stated as merely another language, in which it is an artificial and not a natural language. Semantic explication is the formal mode of meaning representation in the NSM. The NSM approach can develop a fairly sophisticated suite of theoretical construct. Wierzbicka (1996) stated that the basic requirement for metalanguage is to get the satisfaction to communicate the meaning from. As we can see in the action verb; it is said that this type of verb is derived from the 
natural meaning; (a) Type of utterance, (b) Type of the movement, (c) Type of action/doing.

\section{Verb: Memutari}

\begin{tabular}{ll}
\hline \multicolumn{1}{c}{ Source Language } & \multicolumn{1}{c}{ Target Language } \\
\hline $\begin{array}{l}\text { He went around the oven to the } \\
\text { rear, selecting a handful of the dry ruang belakang untuk memilih } \\
\text { grass and stalks standing in the } \\
\text { corner of the kitchen }\end{array}$ & $\begin{array}{l}\text { segenggam rumput kering dan } \\
\text { diletakkan di pojok dapur }\end{array}$ \\
\hline
\end{tabular}

It can be seen from the data above, went around is translated into memutari. According to the Oxford Advanced Learner's, went around means to spin or turn. From the data source above, it can be explicated that the cognitive scenario of this lexicon is:

\section{Went around}

The explication of went around, can be seen as follows:

At that time, $\mathrm{X}$ did something (on foot)

$\mathrm{X}$ did this because of something (to reach another place)

$\mathrm{X}$ did this in something (land)

$\mathrm{X}$ did something like this

In the above data, it can be seen that the verb went around is translated into memutari. According to Kamus besar Bahasa Indonesia, memutari can be meant menggerakkan supaya berputar. It can be meant as a person who can move to another place. It can be seen from the analysis above that the NSM can be stated as an object of the study in its own right. It's stated as an invaluable descriptive tools in the analysis and constrastive study of meaning related in all languages. It is the semantic explication that the formal mode of representing the meaning. However, it depends on the meaning expression. It is said that the 
meaning is not scientific knowledge because it is the meaning that must be explained in simpler way and more easily understood terms.

\section{Memutari}

It can be seen from the characteristic of memutari, here is the explication of memutari as follows:

At that time, $X$ did something (on foot)

$\mathrm{X}$ did this because of something (to reach another place)

$\mathrm{X}$ did this in some places (land, building)

$\mathrm{X}$ did this on something (on purpose)

$\mathrm{X}$ did something like this

The translation of went around into memutari is appropriate because they are stated in the same category of movement verb and they have matched each other.

Verb: menghampirinya

Source Language

Target Language

His father drew near again and put his Ayahnya kembali menghampirinya dan mouth to the crack of the door meletakkan mulutnya di sela-sela daun pintu yang belum sepenuhnya tertutup itu.

It can be seen from the data above, drew had been translated into menghampirinya. According to the Oxford Advanced Learner's, drew means to move by pulling it or them gently. From the above explanation, it can be explicated that the cognitive scenario of this lexicon is as follows: 


\section{Drew}

The explication of "drew" can be seen as follows:

At that time, $\mathrm{X}$ did something (on foot)

$\mathrm{X}$ did this because of something (to reach the person)

$\mathrm{X}$ did this in something (land)

$\mathrm{X}$ did something like this

$\mathrm{X}$ did this on something (on purpose/not on purpose)

According to Kamus Besar bahasa Indonesia, menghampiri means mendekati; datang mendekat. A person wants to reach another person.

\section{Menhampiri}

The configuration of "menghampirinya" can be seen as follows:

At that time, $\mathrm{X}$ did something (on foot)

$\mathrm{X}$ did this because of something (to reach the person)

$\mathrm{X}$ did this in something (ground)

$\mathrm{X}$ did something like this

It can be seen from the translation in data above that drew that is translated into menghampirinya is appropriate because they are in the same category of movement and match each other. The entity of the lexicon above can be stated as the movement verb. It is stated as a movement verb, because the subject moves from one place to another place. The analysis above is stated as the NSM which can be stated as an object of the study in its own right. It's difined as an invaluable descirptive tools in the analysis and constrastive study of meaning related in all languages. It is the semantic explication that the formal mode of representing the meaning. However, it depends on the meaning expression used. It is said that the meaning is not scientific knowledge because it is the meaning that must be explained in simpler way and more easily understood terms. 


\section{Verb: melangkah}

\begin{tabular}{clc}
\hline Source Language & \multicolumn{2}{c}{ Target Language } \\
\hline He went out into the early morning. & $\begin{array}{l}\text { Ia melangkah keluar rumah, } \\
\text { menyongsong datangnya pagi. }\end{array}$ \\
\hline
\end{tabular}

It can be seen from the above translation that went out is translated into melangkah keluar. According to the Oxford Advanced Learner's, went out means to leave your house to go to a social event. From the above explanation, it can be explicated that the cognitive scenario of this lexicon is:

\section{Went out}

The explication of went out, 'melangkah keluar' can be seen as follows:

At that time, $\mathrm{X}$ did something (on foot)

$\mathrm{X}$ did this because of something (to reach another place)

$\mathrm{X}$ did this in something (land)

$\mathrm{X}$ did something like this

According to Kamus Besar Bahasa Indonesia, melangkah means gerakan kaki (ke depan, ke belakang, ke kiri, ke kanan) waktu berjalan. Melangkah keluar is when a person do something to reach another place. Wierzbicka (1996) stated that the predicate in the data above is stated as the action predicate. It is stated that $\mathrm{A}$ and $\mathrm{B}$; (A) $\mathrm{X}$ did something (B) did something to $\mathrm{Y}$. The action verb can come from act done by someone or something in which pick that is included.

\section{Melangkah Keluar}

The explication of "melangkah keluar" can be seen as follows:

At that time, $\mathrm{X}$ did something

$\mathrm{X}$ did this because of something

$\mathrm{X}$ did this in something

$\mathrm{X}$ did something like this 
We can see from the data above that the translation of went out into melangkah keluar is appropriate because they are in the same category of movement and already match each other. The analysis above can be stated as the NSM of an object of the study in its own right. It's difined as an invaluable descirptive tools in the analysis and constrastive study of meaning related in all languages. It is the semantic explication that the formal mode of representing the meaning. However, it depends on the meaning expression. It is said that the meaning is not scientific knowledge because it is the meaning that must be explained in simpler way.

\section{Verb: Menyebrangi}

Source Language Target Language

She went across the fields Ia menyebrangi sawah

It can be seen from the above translation that went across is translated into menyebrangi. According to the Oxford Advanced Learner's, went across means to visit or a place that is near. From data source above that, it can be explicated that the cognitive scenario of this lexicon can be seen as follows:

\section{Went across}

The explication of went across, that is translated into 'menyebrangi' can be seen as follows:

At that time, $X$ did something (on foot)

$\mathrm{X}$ did this because of something (to reach another place)

$\mathrm{X}$ did this in something (land)

$\mathrm{X}$ did something like this

According to Kamus Besar Bahasa Indonesia, menyebrangi means mengarungi; melintasi; melalui (kali, jalan, dsb), menempuh kesukaran (kesulitan $d s b)$. 


\section{Menyebrangi}

It can been that the configuration of 'menyebrangi' is as follows:

At that time, $\mathrm{X}$ did something

$\mathrm{X}$ did this because of something (to reach the place)

$\mathrm{X}$ did this in something (land)

$\mathrm{X}$ did something like this

We can see from the translation above that went across is translated into menyebrangi. The translation is appropriate because they are in the same category of movement verb and they match each other. According Wierzbicka (1996) stated that the predicate in the data above is stated as the action predicate. It is stated that $\mathrm{A}$ and $\mathrm{B}$; (A) X did something (B) did something to Y. The action verb can come from act done by someone or something in which pick that is included.

\section{Verb: melangkah}

\begin{tabular}{cl}
\hline \multicolumn{1}{c}{ Source Language } & \multicolumn{1}{c}{ Target Language } \\
\hline Then, he went to the door of their room & $\begin{array}{l}\text { Setelah itu, ia melangkah menuju } \\
\text { pintu kamar tidur }\end{array}$ \\
\hline
\end{tabular}

It can be seen from the above translation that went to is translated into melangkah. According to the Oxford Advanced Learner's, went to means to move or travel from one place to another. From the explanation above, it can be explicated that the cognitive scenario of this lexicon is as follows:

\section{Went to}

The explication of went to, that is translated into 'melangkah' can be seen as follows:

At that time, $\mathrm{X}$ did something (on foot)

$\mathrm{X}$ did this because of something (to reach another place)

$\mathrm{X}$ did this in something (land) 
$\mathrm{X}$ did something like this

According to Kamus Besar Bahasa Indonesia, melangkah means mengayunkan (menggerakkan) kaki ( $\mathrm{pd}$ waktu berjalan dsb). berangkat; berjalan; melalui; mengarungi: lautan; bertindak; bekerja.

\section{Melangkah}

The configuration of 'melangkah' can be seen as follows:

At that time, $\mathrm{X}$ did something

$\mathrm{X}$ did this because of something (to reach the place)

$\mathrm{X}$ did this in something (land)

$\mathrm{X}$ did something like this

We can see from the above translation that went to is translated into melangkah. The translation is appropriate because they are in the same category of movement and match each other.

\section{Verb: menyusuri}

\begin{tabular}{lll}
\hline \multicolumn{1}{c}{ Source Language } & \multicolumn{2}{c}{ Target Language } \\
\hline $\begin{array}{l}\text { It seemed to him as he walked into the } \\
\text { sharp sunshine of the dusty street }\end{array}$ & $\begin{array}{l}\text { Begitu } \\
\text { menyusuri jalan berdebu yang panas }\end{array}$ \\
\hline
\end{tabular}

We can see from the above translation process that walked into is translated into menyusurinya. According to the Oxford Advanced Learner's, walked into means become caught in unpleasant situation, especially because you are careless. From the above explanation, it can be explicated that the cognitive scenario of this lexicon can be seen as follows:

\section{Walked into}

The explication of walked into, that is translated into 'menyusuri' can be seen as follows: 
At that time, $\mathrm{X}$ did something (on foot)

$\mathrm{X}$ did this because of something (to reach another place)

$\mathrm{X}$ did this in something (land)

$\mathrm{X}$ did something like this

According to Kamus Besar Bahasa Indonesia, 'menyusuri' means menuruti bagian tepi; menelusuri: mengikuti (jejak, kehidupan, dsb).

\section{Menyusuri}

The configuration of 'menyusuri' can be seen as follows:

At that time, $\mathrm{X}$ did something

$\mathrm{X}$ did this because of something (to reach the place)

$\mathrm{X}$ did this in something (land)

$\mathrm{X}$ did something like this

We can see from the above translation that walked into is translated into menyusuri. The translation is appropriate because they are in the same category of movement and match each other. According Wierzbicka (1996) stated that the predicate in the data above is stated as the action predicate. It can be seen from the data above that $\mathrm{A}$ and $\mathrm{B}$; (A) X did something (B) did something to Y. The action verb can come from act done by someone or something in which pick that is included.

Verb: berjalan

Source Language

He walked among his fellows

\section{Target Language}

Ia berjalan di tengah-tengah kawankawannya

It can be seen from the above translation process that walked is translated into berjalan. According to the Oxford Advanced Learner's, walked means to move or go somewhere by putting one foot in front of the other on the ground, but 
without running. From the above explanation, it can be explicated that the cognitive scenario of this lexicon can be seen as follows:

\section{Walked}

The explication of walked, that is translated into 'berjalan' can be seen as follows:

At that time, $\mathrm{X}$ did something (on foot)

$\mathrm{X}$ did this because of something (to reach another place)

$\mathrm{X}$ did this in something (land)

$\mathrm{X}$ did something like this

According to Kamus Besar Bahasa Indonesia, 'berjalan' means melangkahkan kaki bergerak maju, bergerak maju dr suatu titik (tempat) ke titik (tempat) lain, menggelinding atau berputar (sesuatu yg bundar spt roda).

\section{Berjalan}

The configuration of 'berjalan' can be seen as follows:

At that time, $\mathrm{X}$ did something

$\mathrm{X}$ did this because of something (to reach the place)

$\mathrm{X}$ did this in something (land)

$\mathrm{X}$ did something like this

We can see from the translation above that walked is translated into berjalan. The translation is appropriate because they are in the same category of movement and match each other. According Wierzbicka (1996) stating that the predicate in the data above is stated as the action predicate. It can be seen from the data above that $\mathrm{A}$ and $\mathrm{B}$; (A) $\mathrm{X}$ did something (B) did something to $\mathrm{Y}$. The action verb can come from act done by someone or something in which pick that is included. 
Verb: melangkah pergi

\begin{tabular}{lc}
\hline \multicolumn{1}{c}{ Source Language } & Target Language \\
\hline And he went away & Sesudah itu ia melangkah pergi \\
\hline
\end{tabular}

We can see from the translation process above that went away is translated into melangkah pergi. According to the Oxford Advanced Learner's, went away means to leave a person or place; to leave home for a period of time, especially for a holiday/vacation; or to disappear. From the explanation above, it can be explicated that the cognitive scenario of this lexicon is:

The explication of "went away" that is translated into can be seen as follows:

At that time, $\mathrm{X}$ did something (on foot)

$\mathrm{X}$ did this because of something (to reach the person)

$\mathrm{X}$ did this in something (land)

$\mathrm{X}$ did something like this

$\mathrm{X}$ did this on something (on purpose/not on purpose)

According to Kamus Besar bahasa Indonesia, melangkah pergi means mengayunkan (menggerakkan) kaki (pada waktu berjalan dsb) berangkat; berjalan; melalui; mengarungi: bertindak; bekerja. Wierzbicka (1996) stated that the predicate in the data above is stated as the action predicate. It is stated that A and B; (A) X did something (B) did something to Y. The action verb can come from act done by someone or something in which pick that is included.

\section{Melangkah pergi}

The configuration of "melangkah pergi" can be seen as follows:

At that time, $\mathrm{X}$ did something (on foot)

$\mathrm{X}$ did this because of something (to reach the person)

$\mathrm{X}$ did this in something (ground)

$\mathrm{X}$ did something like this 
It can be seen from the above translation that the translation of went away into melangkah pergi is appropriate because they are in the same category of movement and match each other. We can see from the data above that the data were analysed using the theory of Natural Semantic Metalanguage (NSM). Therefore, it can said that the meaning of the verbs can be observed by using the mapping process. Wierzbicka (1996) stated that the predicate in the data above is stated as the action predicate. It is stated that A and B; (A) X did something (B) did something to $\mathrm{Y}$. The action verb comes from act done by someone or something in which pick that is included.

\section{Verb: merangkak}

\section{Source Language}

The children clambered about the sight of the food

\section{Target Language}

Anak-anak merangkak ke atas tangga rumah

It can be seen from the above translation process that clambered is translated into merangkak. According to the Oxford Advanced Learner's, clambered means to climb or move with difficulty or a lot of effort, using your hands and feet. From the explanation above, it can be explicated that the cognitive scenario of this lexicon is:

The explication of "clamber" can be seen as follows:

At that time, $\mathrm{X}$ did something (on foot)

$\mathrm{X}$ did this because of something (to reach up position)

$\mathrm{X}$ did this in something (land)

$\mathrm{X}$ did something like this

$\mathrm{X}$ did this on something (on purpose/not on purpose)

According to Kamus Besar bahasa Indonesia, merangkak means bergerak dng bertumpu pd tangan dan lutut; bergerak lamban tidak pesat kemajuannya. 


\section{Merangkak}

It can be seen that the configuration of "merangkak" as follows :

At that time, $\mathrm{X}$ did something (on foot)

$\mathrm{X}$ did this because of something (to reach up position)

$\mathrm{X}$ did this in something (ground)

$\mathrm{X}$ did something like this

It can be seen from the above translation that the translation of clambered into merangkak is appropriate because they are in the same category of movement and it can be said to be match each other. It can be seen from the data above that the data were analysed deeply using the theory of Natural Semantic Metalanguage (NSM). Therefore, the meaning of the verbs can be observed by applying the mapping process. Wierzbicka (1996) stated that the predicate in the data above is stated as the action predicate. It is stated that A and B; (A) X did something (B) did something to $\mathrm{Y}$. The action verb can come from act done by someone or something in which pick that is included.

\section{CONCLUSIONS AND SUGGESTIONS}

This study has the purpose to focuss on the translation of movement verbs in The Good Earth that was written by Pearl S. Buck. The Natural Semantic Metalanguage (NSM) is applied in the translation process. The novel The Good Earth was chosen as data source because it has two texts which have different language types. This study aims at describing the application of translation procedures that is proposed by Vinay and Darlbener and it is applied to examine the mapping of Action Verbs by the NSM (Natural Semantic Metalanguage) theory. The analysis was shown as the mapping between Indonesian and English action verbs which was presented into the subtype of the verbs based on the classification. This study attempts to apply that theory in solving the problem of the different language. Semantic mapping (SM) is a method in statistics for dimensionality reduction that can be used in a set of multidimensional vectors of features to extract a few new features that preserves 
the main data characteristics. Translation is very important in various areas which are used to translate from one language into another language. However, it is not all the references written in Indonesian as they are coming from different countries and use different languages. The data were analyzed deeply by using the theory of Natural Semantic Metalanguage (NSM). Therefore, by applying the mapping process, the meaning of the verbs can be observed. According to Givon (1984) in his book entitled Syntax: a Functional Typological Introduction, verb can be classified into a couple of typological classification which follow the typological classification model. Action verb; it is said that this type of verb is derived from the natural meaning; (a) Type of utterance, (b) Type of the movement, (c) Type of action/doing. Provide a statement that what is expected, as stated in the "Introduction" chapter can ultimately result in "Results and Discussion" chapter, so there is compatibility. Moreover, it can also be added the prospect of the development of research results and application prospects of further studies into the next (based on result and discussion).

The materials in this research were taken from the novel entitled The Good Earth. It can be seen from the data source in the novel that the story is stated to be fiction or narrative story. The novel was chosen by the author as these novels were performed in two languages which were in the form of Indonesian and English. It is important to get the collected data by reading and documenting technique which was considered that is related to problems. We can see that the data were then compiled by reading Indonesian and English novel. The qualitative method and library research were used in analysing data in this article. The appropriate data were then analysed in order to get deeply research. There are some eliminations of the data used in finding the appropriate data in analyzing the data. The author only choose the data that were really needed by the author with some requirements used in supporting this study. The data were then analysed by using the theory that is proposed by Wierzbicka (1996). This studi used the theory proposed by Wierzbicka (1996) stated that the predicate in the data above is stated as the action predicate. It is stated that $\mathrm{A}$ and $\mathrm{B}$; (A) $\mathrm{X}$ did something (B) did something to $\mathrm{Y}$. The action verb comes from act done by someone or something 
in which pick that is included. The explications are in the intuitive senses for native speakers. The another condition is in well-formedness. They need to be framed entirely in the semantic primes or molecules in order to conform for the syntax of the natural semantic metalanguage. It is stated that over the 35 years since Wierzbicka's (1972) Semantic Primitives, the NSM program has been converted into new models of semantic explication. The analysis in the results and discussion can be stated as the NSM of an object of the study in its own right. It can be stated as an invaluable descirptive tools in the analysis and constrastive study of meaning related in all languages. It is stated as the semantic explication that the formal mode of representing the meaning. However, it depends on the meaning of expression. It can be meant that the meaning is not scientific knowledge because it is the meaning that must be explained in simpler way.

\section{REFERENCES}

Bassnett, Susan. 1991. Translation Studies. London: Routledge

Bassnett, Susan. 2011. Topic in Translation: Reflections on Translation. Bristol: Multilingual Matters

Bell, R.T. 1991. Translation and Translating: Theory and Practice. London: Longman

Dwijati, Ida Ayu Kade. 2015. A Methodology for Translation of Figurative Senses in 'Makhluk di Belakang Rumah' and in 'Creatures Behind Houses'

Hornby, Mary Snell et al. 1992. Translation Studies: An Interdiscipline. Philadelphia: John Benjamin Publishing Company

Larson, Mildred.L. 1998. Meaning - Based Translation. Maryland: University Press of America.

Newmark, Peter. 1988. A Textbook of Translation. Hertfordshire: Prentice Hall International (UK) Ltd

Nida, Eugene A \& Charles R. Taber. 1974. The Theory and Practice of Translation. Leiden: E.J. Brill

Nida, Eugene A. 1975. Language Structure and Translation. California: Stanford University Press

Pratami, Ni Wayan Cintya Surya. 2015. A Methodology for Translation of Figurative Senses in 'Tanpa Kemudian' and in 'No Resolution'

Venuti, Lawrence. 2000. The Translation Studies Reader. London: Routledge 